\title{
Integrating Web 2.0 technology into the curriculum to promote constructivist learning
}

Author: Harsha Parmar. Manchester Pharmacy School, The University of Manchester

Background: Pharmacy students are required to become lifelong self-directed learners; as educators our role is to provide learning opportunities for students to develop this skill. Constructivist-learning environments can promote such opportunities. ${ }^{1,2}$ As part of the assessment of first-year pharmacy students, a novel assessment was introduced which assessed knowledge and application of the role of the pharmacist in an allocated community-pharmacy service provision through production of a 60-second YouTube video, following a series of workshops on service provision. An evaluation of student's views of the skills utilised in completion of this task, and the mode in which learning occurred, was undertaken.

Method: A 14-item questionnaire was developed to capture the skills that respondents felt they had utilised through completing this task, and, how they had developed their understanding of the allocated topic. The questionnaire was administered to all first-year students in an identified lecture slot using polling software.

Results: $71 / 152$ students participated in the questionnaire. To ask respondents what skills they felt they utilised through completion of this task, a series of statements was listed that they responded to using a 5-point Likert scale. Table 1 summarises these responses;

\begin{tabular}{lcc}
\hline & $\boldsymbol{n}$ & $\begin{array}{c}\text { \% who 'agreed' with } \\
\text { statement }\end{array}$ \\
\hline $\begin{array}{l}\text { Applied critical -thinking skills } \\
\begin{array}{l}\text { Applied problem-solving } \\
\text { skills }\end{array}\end{array}$ & 28 & 44.4 \\
$\begin{array}{l}\text { Applied principles of } \\
\text { professionalism in an online } \\
\text { environment }\end{array}$ & 29 & 44.6 \\
$\begin{array}{l}\text { Learnt through discovery } \\
\text { Mediated my own learning }\end{array}$ & 34 & 57.6 \\
\hline Table 1: Skills developed through completing the task & \\
\hline
\end{tabular}

Conclusion: Previous research has focussed on integrating Web 2.0 technology to promote the pharmacist's role. ${ }^{3}$ This study highlights how integration of Web 2.0 technology to assimilate knowledge and practice, could, in some students, promote a constructivist-learning environment which can help students develop higher-order thinking skills associated with becoming a self-directed learner.

\section{References}

1. Kaufman D. Applying educational theory in practice. BMJ. (2003) 326(7382): 213-216.

2. Kang L.O., Brian S., Ricca B. Constructivism in pharmacy school. Currents in Pharmacy Teaching and Learning (2010) 2(2);126-130.

3. Seena L. Haines, Jenny A. Van Amburgh. A Vidcasting Project to Promote the Pharmacist's Role in Public Health. American Journal of Pharmaceutical Education. 2010 August 10; 74(6): 97. 